\title{
A vendéglátás nemzetközi kutatási paradigmái a Covid19 árnyékában Szisztematikus szakirodalmi áttekintés és egy koncepcionális keretmunka
}

\author{
Research paradigms for restaurant \\ management worldwide in Covid19 \\ Systematic literature review and \\ a conceptional framework
}

\begin{abstract}
Szerzők: Debreceni János' - Fekete-Frojimovics Zsófiaª
A koronavírus-járvány soha nem látott kihívás elé állította a turizmus-vendéglátás szereplőit világszerte. A válsághelyzettel való küzdelem a vállalkozások üzleti modelljének átalakítását, a vendégek kényszerủ alkalmazkodását vonta maga után. A vendéglátásban tapasztalható jelenségekről számos cikk jelent meg a nemzetközi tudományos szakirodalomban. Jelen tanulmány célja egyrészt az aktuális ismeretelméleti megközelítések (vállalatelmélet, marketing, fogyasztói magatartás és szervezeti magatartás) rendszerezése, ami segíti a járvány vendéglátásra gyakorolt hatásának tudományos vizsgálatát, másrészt egy, a vendéglátó mikro- és kisvállalkozásokra irányuló kutatási keretmunka bemutatása olyan változók bevonásával, mint a tervezett és alkalmazkodó reziliencia, a pénzügyi teljesítmény, a fenntartható turizmusfejlődés és az állami segítségnyújtással való elégedettség.
\end{abstract}

The coronavirus pandemic has caused an unprecedented challenge to tourism and hospitality operators worldwide. Coping with the crisis led to the transformation of the enterprises' business models and to mandatory adaptation by guests. A number of studies of the restaurant industry have been published in the international scientific literature. The aim of the present study is, on the one hand, to systematize the epistemological approaches (corporate theories, marketing, consumer behavior, and organizational behavior) emerging in the latest literature, thus helping to examine the impact of the pandemic on hospitality. On the other hand, it offers the interpretation of a research framework for hospitality SMEs, including variables such as planned and adaptive resilience, financial performance, sustainable tourism development and satisfaction with state aid.

Kulcsszavak: vendéglátás, reziliencia, válságmenedzsment, fenntarthatóság. Keywords: hospitality, resilience, crisis management, sustainability.

\section{Bevezetés}

A 2020 tavaszán világszerte megjelenő Covid19 koronavírus (továbbiakban Covid) és annak meg- fékezésére bevezetett járványügyi intézkedések a gazdaság valamennyi területére hatással voltak. A turizmus-vendéglátás ágazatát alapjaiban befolyásolták a szabad helyváltoztatást és társas érintkezést korlátozó döntések. A kérdésre, hogy a piaci szereplók alkalmazkodása mennyire tartósan alakította át a fogyasztói szokásokat és az üzleti gyakorlatokat, az elkövetkezó évek tudományos kutatásai fognak választ adni.

\footnotetext{
tanársegéd, Budapesti Gazdasági Egyetem, debreceni.janos@uni-bge.hu

docens, Budapesti Gazdasági Egyetem, fekete-frojimovics.zsofia@uni-bge.hu
} 
Jelen tanulmány célja kettős: egyrészt (O1) annak feltárása, hogy milyen tudományos paradigmákból érdemes a megváltozott üzleti gyakorlatokat és fogyasztói percepciókat vizsgálni a vendéglátásban; másrészt $(\mathrm{O} 2)$ egy, a magyarországi vendéglátó vállalkozások rezilienciájának vizsgálatára alkalmazható koncepcionális keretmunka bemutatása. A célkitúzések teljesítése serkentóleg hathat a Covid utáni turizmus-vendéglátás tárgykörében végezhetó empirikus kutatásokra és ismeretalkotásra. A tanulmány primer adatgyújtést és elemzést nem tartalmaz. A paradigmák azonosítása szisztematikus szakirodalmi áttekintéssel történt, a koncepcionális keretmunka pedig a szakirodalomból levont következtetések és iparági tapasztalatok alapján készült.

\section{A Covid vendéglátásra gyakorolt hatása}

Éves összevetésben 2019-re a világ turizmusa minden addiginál nagyobbra nőtt. A STATISTA (2020a) szerint a turizmus világgazdasághoz való hozzájárulása közvetlenül 2,9 billió, közvetetten 9,25 billió amerikai dollár volt, miközben a turisztikai érkezések száma 1,46 milliárdra nőtt. 2019-ben a szabadidős turisták 4,69 (STATISTA 2020b), az üzleti utazók pedig 1,29 billió dollárt (STATISTA 2020c) költöttek.

Az első, Covid miatti megbetegedések 2019 decemberében történtek a közép-kínai Hupej tartomány székhelyén, Vuhanban. A fertózés gyorsan terjedt, aminek következtében 2020 márciusában a legtöbb ország be- és kiutazási tilalmat vezetett be, korlátozta az országon belüli mozgást és a társas érintkezéseket, valamint a személyes érintkezéssel járó szolgáltatásokat (vendéglátás, oktatás, szabadidős tevékenységek). Az intézkedések által leginkább sújtott ágazat a turizmus volt. A turizmus indikátorai néhány hét leforgása alatt lenullázódtak, éves összehasonlításban pedig felére estek vissza: a szabadidős költések 50\%-kal (STATISTA 2020b), az üzleti költések több, mint 60\%-kal (STATISTA 2020c) csökkentek.

A vendéglátás - különösen az éttermi és szállodai vendéglátás - a turizmus elválaszthatatlan részét képezi. 2017-ben a turizmus szatellitszámlák szerint a vendéglátásban $26,1 \%$ volt a turisztikai fogyasztás aránya (HINEK 2020). A Covid elleni védekezést világszerte eltéróen terjesztették ki a vendéglátásra. Magyarországon az éttermi szolgáltatás többszöri korlátozásnak és enyhítésnek volt tárgya. Az éttermeknek és kávézóknak először 15:00-kor be kellett zárniuk (2020. március 16.), majd kizárólag elviteles értékesítést és házhoz szállítást folytathattak (2020. március
28.). Az elsó, 2020. május 18-i újranyitás jelentôs fellendülést hozott, de a lendületet először a szeptember elsejei határzár, majd a november 11-i korlátozások megtörték. Az éttermek ismételten csak elvitelre és házhoz szállításra értékesíthettek egészen 2021. április 24-ig, amikortól a kerthelyiségekben és teraszokon már fogadhattak vendéget, majd április 29 -tól a védettségi igazolvánnyal rendelkezô vendégek az éttermek belső vendégterében is fogyaszthattak.

A korlátozások kedvezôtlen hatásairól a kereskedelmi vendéglátás teljesítményének változása tanúskodik. A Központi Statisztikai Hivatal szerint 2019-hez képest 30\%-kal, 950 milliárd forintra zsugorodott a szektor (KSH 2021). A NEMZETI CÉGTÁR (2021) adatbázisa alapján 2021 második negyedévében 2,5\%-kal kevesebb éttermi, mozgó vendéglátást folytató vállalkozás múködik, amelyeknél 22,4\%-kal kevesebb alkalmazott dolgozik, mint egy évvel korábban. Az elszenvedett károkat jól mutatja, hogy az ágazat indikátorai a 2016-os évet tükrözik és a 2019-es év teljesítményének elérése vélhetően évekbe telik. Ezalatt az idő alatt azonban a piaci szereplóknek a bizonytalansághoz, a változó vendégigényekhez és múködési feltételekhez kell alkalmazkodniuk. Hogy mik lehetnek a releváns kutatási területek és tudományelméleti megközelítések, arra az $\mathrm{O} 1$ adhat választ.

\section{A szisztematikus szakirodalmi áttekintés cikkei}

A szakirodalmi áttekintés alapját a Google Scholar és ScienceDirect keresőoldalakon fellelhetô tudományos folyóiratcikkek képezték. A szûrés 2021. január 25. és 31. között történt az alábbi keresőszavak használatával: covid, restaurant, hospitality, guest (magyar nyelven covid, étterem, vendéglátás, vendég). Körülbelül ezer cím és több száz absztrakt feldolgozását követôen 24 tudományos folyóiratcikk felelt meg az O1 teljesítéséhez szükséges tartalmi elvárásoknak, vagyis ennyi publikációban foglalkoztak kifejezetten vagy érintólegesen a Covid és az éttermek kapcsolatával. A vizsgálatba vont folyóiratokat, azok impaktfaktorát és Scimago szerinti besorolását az 1. táblázat foglalja össze.

A tanulmányok többségében saját empirikus kutatáson alapuló eredményeket mutattak be. 12 kutatás az Egyesült Államokban készültt, míg Európát osztrák, portugál, angol és török minták reprezentálták, de végeztek megkérdezést Taipeiben, Makaóban és Egyiptomban is. A nem empirikus kutatáson alapuló közleményben országhelyzet ismertetésével (Brazília), metaanalízissel és szövegelemzéssel találkozunk. 
Forrásként használt folyóiratok listája

\begin{tabular}{|l|c|c|c|}
\hline \multicolumn{1}{|c|}{ Folyóirat } & $\begin{array}{c}\text { A szakirodalmi } \\
\text { áttekintés } \\
\text { publikációinak } \\
\text { száma }\end{array}$ & $\begin{array}{c}\text { Impakt- } \\
\text { faktor } \\
\mathbf{2 0 1 9}\end{array}$ & $\begin{array}{c}\text { Scimago } \\
\text { besorolás } \\
2019\end{array}$ \\
\hline $\begin{array}{l}\text { International Journal } \\
\text { of Hospitality } \\
\text { Management }\end{array}$ & 18 & 6.701 & $\mathrm{Q} 1$ \\
\hline $\begin{array}{l}\text { Cornell Hospitality } \\
\text { Quarterly }\end{array}$ & 1 & 2.800 & $\mathrm{Q} 1$ \\
\hline $\begin{array}{l}\text { Current Issues in } \\
\text { Tourism }\end{array}$ & 1 & 4.147 & $\mathrm{Q} 1$ \\
\hline $\begin{array}{l}\text { Food Research } \\
\text { International }\end{array}$ & 1 & 4.972 & $\mathrm{Q} 1$ \\
\hline $\begin{array}{l}\text { International Journal } \\
\text { of Environmental } \\
\text { Research and Public } \\
\text { Health }\end{array}$ & 1 & 2.849 & $\mathrm{Q} 2$ \\
\hline $\begin{array}{l}\text { Journal of Hospitality } \\
\text { and Tourism } \\
\text { Management }\end{array}$ & 1 & 3.415 & $\mathrm{Q} 1$ \\
\hline Sustainability & 1 & 2.576 & $\mathrm{Q} 2$ \\
\hline
\end{tabular}

Forrás: saját szerkesztés

\subsection{A TANULMÁNYOKBAN ALKALMAZOTT PARADIGMÁK, TUDOMÁNYOS MEGKÖZELIITÉSEK}

$\mathrm{Az}$ áttekintésbe bevont szakirodalmak közül 20 támaszkodik valamilyen paradigmára, elméleti háttérre vagy keretmunkára, illetve több paradigma egyidejú érvényesítésére. 5 folyóiratcikkben elméleti keretmunka nélkül mutatják be eredményeiket a szerzők, míg valamennyi közleményben a Covid és annak megfékezésére irányuló intézkedések vendéglátásra gyakorolt hatását vizsgálják. A paradigmákat és az elméleti kereteket az 1. ábra foglalja össze.

A vállalatelmélet képviselôi közül SONG és társai (2021) azt vizsgálták, hogy az Amerikai Egyesült Államokéttermivállalatainakstratégiái közül melyek bizonyultak hatékonyabbnak a Covid-krízisben. Kiderült, hogy a járványhelyzet a nagyobb méretú és tôkeáttételú, illetve több likvid pénzeszközzel rendelkező éttermi vállalatok részvényhozamaira kevésbé volt hatással. A vállalatok nemzetközisége és a magasabb eszközmegtérülési mutató (ROA) szintén enyhítette a járvány tőkepiaci hatását, viszont a franchise múködés nem befolyásolta a

Paradigmák és elméleti keretek összefoglalása
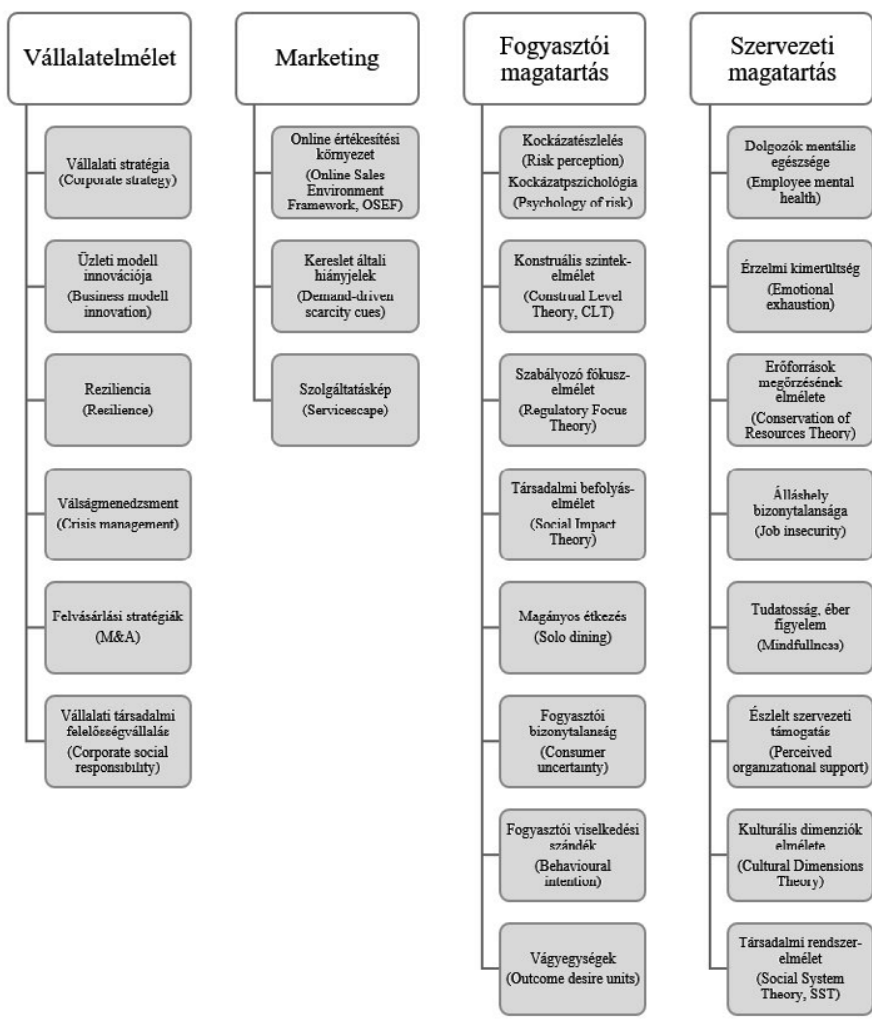

Forrás: saját szerkesztés 
részvénypiaci folyamatokat. MUN és társai (2021) szintén amerikai éttermi vállalatokat vizsgáltak, de a cégfelvásárlási stratégiák (MEA) szempontjából. A felvásárlási stratégiák, mint keretrendszer relevanciáját az a várható felvásárlási hullám adja, ami valószínúleg a járványügyi intézkedések feloldását követi majd. A felvásárló éttermi vállalat M\&A előtti profitabilitása jobban befolyásolja az M\&A utáni profitabilitását, mint az értékesítési teljesítménye. OU és társai (2021) az éttermek lehetséges koevolúciós folyamatait vették számba a válságmenedzsment és vállalati társadalmi felelósségvállalás tükrében. Rámutattak arra, hogy ugyan az éttermek stratégiái elsősorban a szolgáltatás megvalósítására, a vendégigények kielégítésére és a bevételszerzésre irányultak, azokkal együtt CSR szempontok is érvényesültek: például a dolgozók jó fizikai és mentális egészségének megőrzését célzó intézkedések. Az ételszolgáltató ágazatban határozott elmozdulás tapasztalható a jótékonyság, a filantrópia irányába. Jó példa erre az egészségügyi dolgozóknak megrendelt és felajánlott ételek, vagy a helyi közösségek gyứjtése és összefogása a bajban lévők megsegítésére. Nagy éttermi vállalatok a következő generációs szakemberek (egészen a farmerekig visszamenóleg) erôsítésére, és az élelmiszeripar fenntarthatóbbá tételére vezetnek be kezdeményezéseket, ösztöndíjakat, képzéseket. A válságmenedzsment elméleti kereteibe illeszkedik MADEIRA és társainak (2020) tanulmánya arról, hogyan vélekednek tulajdonosok és menedzserek a vendéglátás túlélési lehetőségeirôl Portugáliában. A piaci szereplők pesszimistaként, ellenállóként, bizonytalanként és opportunistaként csoportosíthatóak, legfontosabb elvárásaik az állandó múködési költségek finanszírozása, a munkahelyek megtartására indított programok, a nulla kamattal folyósítható vállalkozási hitelek, valamint a bürokrácia és az adók csökkentése.

BREWER és SEBBY (2021) bizonyították, hogy az ételek vizualitása, az ételekről adott információ, az ételrendelés kényelme, valamint a vevők által érzékelt Covid-kockázat erôsítik a rendelés iránti vágyat. Mindez az online értékesítési környezet elméleti keretébe (OSEF) illeszkedik, mivel az OSEF a kiterjesztett inger-válasz (S-O-R) modellek egyike. Online értékesítés során ugyanis a vásárlási felület minősége ingerként hat a fogyasztókra, befolyásolva döntésüket. 2020 tavaszán valamenynyi országban tapasztalható volt a pánikszerú árufelhalmozás in-store és online értékesítésben egyaránt. A jelenséget a kereslet általi hiányjelek elmélete magyarázza, amit a vendéglátásban LI és társai (2021) vizsgáltak. Hiányjelek hatásáról akkor beszélhetünk, amikor a vevô úgy érzékeli, hogy az adott termék vagy szolgáltatás iránti kereslet szélsőségesen megnövekedett, és ez növeli vagy csökkenti saját vásárlási hajlandóságát. LI és társai (2021) a Covid miatti korlátozások során bizonyították, hogy a fokozott kereslet miatti hiányjelek észlelése csökkenti a szolgáltatás igénybevételének szándékát és preferenciáját, ami a biztonságérzet csökkenésével magyarázható. A negatív hatást enyhíti, ha a fogyasztás helyszíne kevésbé zsúfolt, vagy ha a fogyasztás körülményeiről több információ áll rendelkezésre. Szintén a marketing tárgykörébe tartozik a szolgáltatáskép és az étteremkép vizsgálata. TAYLOR (2020) bizonyította, hogy egy étteremben a biztonságos távolság betartására a vendégek jobban elfogadják az asztalok paravánnal való elválasztását, mint az élethú bábuk székekre ültetését. Továbbá éttermi fogyasztás esetén a 40 év fölöttiek jobban megkövetelik a távolságtartást. Az egészségügyi kockázat csökkentésére tett óvintézkedések megjelennek a vendégek szolgáltatásminőséggel kapcsolatos, úgynevezett vágyegységei (outcome desire unit) között is.

A szolgáltatásképhez szorosan kapcsolódnak azok az éttermi attribútumok, amiket CHOI és szerzótársai (2020) a magányos étkezés (solo dining) vizsgálatába vontak be. Az autentikus kínai éttermekben a magányos étkezés pozitív érzelmekkel párosul. Eredményeik szerint a magányos étkezés legfontosabb motivációi a fogyasztói döntési szabadság és az éhség csillapítása, színhelyei pedig inkább a gyorséttermek. Ezt a szokást az életvitel, a foglalkozás és az életkor jelentősen befolyásolja. Az érzékelt kockázat a marketing átfogóbb paradigmái mellett a fogyasztói magatartásban is érvényesül. BYRD és társai (2021) nagymintás kutatás alapján állapították meg, hogy az ételcsomagolásokkal szemben mérsékelt félelem tapasztalható, mivel a megkérdezettek éttermi fogyasztás esetén az ételt tartják az elsődleges kockázati tényezőnek, ugyanakkor kockázatosnak tartják a harmadik fél általi ételkiszállítást. KIM és LEE (2020) más vendégek jelenlétének hatását vizsgálva bizonyították, hogy az észlelt koronavírus-kockázat növeli a többi vendég elkerülésének szándékát, és azt, hogy a privát étkezőhelyiségek és privát asztalok megoldást jelenthetnek az észlelt veszély csökkentésére. FOROUDI és társai (2021) bizonyították, hogy az észlelt egészségügyi kockázat erôsíti a kapcsolatot a fogyasztók meggyőződése és az anticipációs érzelmeik között. A kockázat a konstruális szintek elméletébe (CLT) illeszkedik, ami azt jelenti, hogy az egyének mást gondolnak egy adott cselekvésről, ha ők maguk is részesei, és megint mást, ha csak szemlélői. CAI és LEUNG (2020) az online ételrendelés kontextusában vizsgálták a konstruktív gondolkodás és kockázatészlelés összefüggéseit. Bizonyították, hogy a konstruktív gondolkodás és az ételrendelési hajlandóság között 
az önhatékonyság közvetít. A konstruktív gondolkodás ételrendelésre gyakorolt hatását moderálja, hogy a vevő mennyire tartja kockázatosnak a vásárlást. KIM és társai (2021) az éttermek Covidkorlátozások alatti múködését vizsgálták, az ügyfélbizonytalanság bevonásával. Az elmélet szerint a fogyasztó a döntési helyzetben igyekszik minél több konkrét információt gyưjteni a bizonytalanság csökkentése és a döntés kimenetelének minél pontosabb előrejelzése érdekében. Bizonyított, hogy a minőségjelek, szimbólumok vagy a márka jelentősen csökkentik a bizonytalanságot, sőt még az árkedvezményeknél is fontosabbak lehetnek a vevők számára. Ennek oka, hogy az étel kiválasztása során a vevók azt az értéktöbbletet keresik, ami enyhíti a biztonsággal kapcsolatos aggályaikat.

A WHO (2004) a mentális egészségen azt a jólléti állapotot érti, amelyben az egyén meg tudja valósítani önmagát, képes megbirkózni az élet általános stresszhelyzeteivel, valamint produktívan és eredményesen járul hozzá a közösség teljesítményéhez. BUFQUIN és társai (2021) éppen a Covid-korlátozások alatt vizsgálták olyan változók összefüggéseit, mint a foglalkoztatás jellege, a pszichológiai jóllét, a distressz, az alkohol- és kábítószer-fogyasztás, valamint a pályaelhagyási szándék. Eredményeik szerint a distressz fokozza az alkohol- és kábítószer-fogyasztást, valamint a pályaelhagyási szándékot. A Covid-korlátozások alatt dolgozók és a tartós szabadságon lévők közti különbség szignifikáns: a dolgozók nagyobb szorongást és fokozottabb szerhasználatot mutatnak a tartós szabadságon lévőkkel szemben. Hozzá kell tenni azonban, hogy a kutatást az Egyesült Államokban végezték, ahol jelentôs kompenzációban részesültek a munkájukat elvesztôk vagy tartós szabadságon lévők, miközben a munkát végzők az egészségügyi kockázatok miatt megnövekedett munkahelyi stressznek voltak kitéve. CHEN és EYOUN (2021) ugyancsak egyesült államokbeli kutatása szerint a vendégtéri dolgozók koronavírustól való félelme pozitív kapcsolatban áll az érzelmi kimerültséggel és a munkahely bizonytalanságának érzetével. A munkahelyi bizonytalanság - a munkahely elvesztésétól való félelem - közvetítő szerepet tölt be a koronavírus miatti félelem és az érzelmi kimerültség között. A tudatosság, az éber figyelem (mindfulness) és az észlelt szervezeti támogatás enyhítik a koronavírus miatti félelem munkahelyi bizonytalanságra gyakorolt hatását, ezzel közvetlenül a dolgozók, közvetetten pedig a vendégek elégedettségét növelhetik. SHAPOVAL és társai (2021) a társadalmi rendszerelmélet (SST) keretein belül menedzserek és tulajdonosok megkérdezésével vizsgálták a Covid vendéglátásra gyakorolt hatását. Az SST szerint a társadalmat felépítő egyéni és közösségi szintû alcsoportok egymással kölcsönös interakcióban állnak, és az esemény, ami egyik alcsoportban történik, szükségszerúen hatással van a többi alcsoportra. A megkérdezettek véleményében a munkatársak felé tanúsított együttérzés és empátia, a mély családi és baráti kapcsolatok, valamint a kevésbé anyagias és teljesítményorientált értékek érvényesültek. Mindemellett érzékelhető a járványhelyzet vendéglátásra, mint pályamodellre gyakorolt negatív hatása, kérdésessé vált ugyanis, hogy megéri-e fejlődni és fejleszteni ebben az ágazatban?

\section{A saját kutatási keretmunka elméleti alapjai}

Szisztematikus szakirodalmi áttekintés alapján jelölhetô ki az a paradigma, amin keresztül a koronavírus vendéglátásra gyakorolt tartós hatása a minősített folyóiratok elvárásainak megfelelően vizsgálható. Kézenfekvők lehetnek a fogyasztói nézőpontok, de a házhoz szállítás és az elviteles értékesítés vizsgálatához vagy Big Data kutatásra lenne szükség (lásd LI et al. 2021) vagy olyan, validált skálákkal végzett kutatásra (például BREWER-SEBBY 2021), ami a helyben fogyasztás újbóli lehetőségével vélhetően sokat veszít aktualitásából. Emellett a kockázat, a fogyasztói bizonytalanság vizsgálatának relevanciáját a vendéglátóhelyek 2021. április 24-i nyitása óta tapasztalt vendégforgalom erősen megkérdôjelezte. Fontos lenne a Covid szervezeti magatartásra gyakorolt hatásainak vizsgálata is, de a kutatási eredményeket könnyen torzítanák a korlátozások miatt folytatott túlélési stratégiák, a dolgozók körében tapasztalható kiábrándultság és pályaelhagyás, valamint a központi költségvetési támogatások nemzetközi összehasonlításban alacsony szintje. Ezért a vállalati stratégiák felé fordultunk, melyek közül a rezilienciát, a vendéglátó vállalkozások ellenállási képességét választottuk egy koncepcionális keretmunka központi elemeként (O2).

\subsection{REZILIENCIA: RUGALMAS ELLENÁLLÁSI KÉPESSÉG A VENDÉGLÁTÁSBAN}

CUTTER és szerzőtársai (2013) szerint a reziliencia a nemkívánatos eseményekre való felkészülés, az azokhoz való alkalmazkodás és az azokból való felépülés képessége. Nem fér hozzá kétség, hogy a Covid-járványhelyzet egy nemkívánatos, előre nem látható esemény. DE FREITAS és STEDEFELDT (2020) szerint a vendéglátó vállalkozásoknak a korlátozások során elszenvedett károkból csak az ellenállási képesség fejlesztésével érdemes felépülniük, mégpedig négy tarto- 
mány - fizikai, információs, kognitív és közösségi - egyidejú helyreállításával (LINKOV-TRUMP 2019), amit a vendéglátásra a következőképpen adaptáltak. Fizikai a szolgáltatás infrastruktúrája; információs a vendégek döntéshozatalát segítő és befolyásoló - elsôsorban online - adathalmaz; kognitív a szolgáltatás által érintett személyek észlelései, meggyőződései, az általuk elfogadott normák és azok gyakorlati alkalmazása; közösségi pedig a közösség támogatását, szerepvállalását jelenti, ami jelen helyzetben az egészségügyi kockázatok csökkentésére is kiterjed. Rámutattak arra, hogy a múltban folytatott tevékenységek felülvizsgálata, átértékelése, és egyáltalán az emlékezés nélkül nem lehet olyan ellenállási képességet fejleszteni, ami jövőbeli kihívások során a hatékony alkalmazkodás alapját jelentené.

SOBAIH és társai (2021) mikro, kis és közepes turisztikai vállalkozás (szállodák és hagyományos éttermek) ellenállási képességét vizsgálták Egyiptomban. Koncepcionális keretmunkájuk a tervezett (planned) és az alkalmazkodó (adaptive) reziliencia, a vállalati teljesítmény és a fenntartható turizmusfejlesztés összefüggéseire épült. A tervezett reziliencia a válsághelyzet előtt már létező, a vállalat által kidolgozott stratégia. Ellenben az alkalmazkodó reziliencia a krízishelyzet hatására fejlődik ki, és általában szükséges hozzá a jó vezetés, a külsó kapcsolatok, a belsô együttmúködés, a személyzet hogyléte és a múltbéli tapasztalatokból való tanulás képessége (LEE et al. 2013). SOBAIH és társai (2021) valamennyi előfeltételezésüket bizonyították, miszerint a kis szállodai és éttermi vállalkozások tervezett rezilienciája pozitívan befolyásolja az alkalmazkodó rezilienciát, a vállalati teljesítményt, valamint a fenntartható turizmusfejlesztést.

PRAYAG és társai (2018) Új-Zéland Canterbury régiójában múködő turisztikai vállalkozásokat (szálláshely-szolgáltatás, személyszállítás és attrakció múködtetése) vizsgáltak, egy nemkívánatos és tragikus esemény, a 2011-es földrengés tükrében. SOBAIH és társai (2021) cikkétôl eltérôen a tervezett és az alkalmazkodó reziliencia pénzügyi teljesítményre gyakorolt hatását vizsgálták, a kategorikus változók pedig a vállalkozások mérete és tevékenysége voltak. Bizonyították, hogy a tervezett reziliencia pozitívan befolyásolja az alkalmazkodó reziliencia kifejlődését, de a pénzügyi teljesítményre nincs hatással. Nem úgy az alkalmazkodó reziliencia, ami pozitívan befolyásolja a vállalkozás pénzügyi teljesítményének alakulását. A kategorikus változók közül a pénzügyekre egyedül a vállalat mérete van hatással. Összességében az ellenállási képesség egy erôs prediktor változója a vállalkozás pénzügyi teljesítményének krízishelyzetben.

\section{Saját kutatási keretmunka}

A reziliencia, ellenállási képesség hazai vállalati környezetben is jól alkalmazható elméleti keretrendszernek ígérkezik, tudományos és szakmai szempontból egyaránt releváns kutatási eredményeket tartogat. Lehetôvé teszi annak megismerését, hogy az érintett vállalkozások mennyire voltak felkészülve egy elhúzódó válsághelyzetre, beépítik-e múltbeli tapasztalataikat a felépülés, a válsághelyzetből való kilábalás folyamatába, és vannak-e elképzeléseik, terveik jövőbeli nemkívánatos események bekövetkezésének esetére. Kutatási keretmunkánk tárgyát a vendéglátó vállalkozások rezilienciája képezi. Az eddigi tapasztalatokból már körvonalazódik, melyek azok az összefüggések, amelyek értelmezhetóek hazai vállalkozási környezetben és tesztelhetőek a minősített nemzetközi folyóiratok elvárásainak megfeleló módszertannal. Utóbbi a nemzetközi disszeminációs lehetőségek szúk keresztmetszete. Az egyik leggyakoribb, kvantitatív módszertanhoz tartozó adatelemzési módszer a megerôsítő faktoranalízis (confirmatory factor analysis), illetve annak különböző eljárásai, mint az útvonalelemzés (path analysis) vagy a strukturális egyenletek modelljei (structural equation modelling) közé tartozó kovariancia-alapú (CB-SEM) és variancia-alapú (PLS-SEM) módszer. A különböző módszerek alapjaiban határozzák meg az adatgyưjités módját. Megerôsítő faktoranalízis jellemzően csak olyan, feltáró faktoranalízissel azonosított modellen alkalmazható, melynek alapját validált mérési skálával rögzített adatbázis képezi. A validált mérési skálák alkalmazása nagyon gyakori a menedzsment szakirodalomban, a hazai turizmus-vendéglátás kutatásban azonban még nem kellóen kiaknázott, ami kutatási rés. Újszerû eredményekhez vezethet a járványhelyzet alatti ellenállási képesség (current state) és a jövőbeli vállalati elvárások (should be vagy future state) összevetése is.

Az adatgyưjjés során négy validált skálát alkalmaznánk, melyekból a tervezett reziliencia (PR), az alkalmazkodó reziliencia (AR), a pénzügyi teljesítmény $(\mathrm{FP})$ és a fenntartható turizmusfejlesztés (STD) faktorok hozhatók létre. A faktorok közti kapcsolatokat, egyúttal a megerősítő faktoranalízis lehetséges mérési modelljét, a 2. ábra jeleníti meg. Az ábrán további négy kategorikus változó látható: a vendéglátó vállalkozások tevékenysége (éttermi, mozgó vendéglátás, italszolgáltatás, rendezvényi étkeztetés) és az állami segítségnyújtással való elégedettség. Lényeges iparági eredmény lehet ugyanis annak feltárása, hogy van-e különbség a különbözô vendéglátó tevékenységet folytatók, illetve az állam válság alatti szerepvállalásával elé- 
gedett vagy elégedetlen szereplők pénzügyi teljesítménye között. Ezt az összefüggést szeretnénk megvizsgálni egy másik függő változó, a fenntartható turizmusfejlesztés vonatkozásában. A szakirodalmi áttekintés alapján ugyanis fontos felismerésnek tartjuk, hogy a válságból való kilábalás csak a fenntartható szemlélet erős integrációja mellett
2. táblázat foglalja össze. Látható, hogy mindhárom szakágazatban csökkent a vállalkozások és az alkalmazottak száma, valamint az éves nettó árbevétel. A csökkenést a százalékos értékek jelzik az előzó évhez képest, amik alapján megerősíthetó, hogy a kereskedelmi vendéglátás helyzete válságos.

\section{A koncepcionális keretmunka lehetséges modellje}

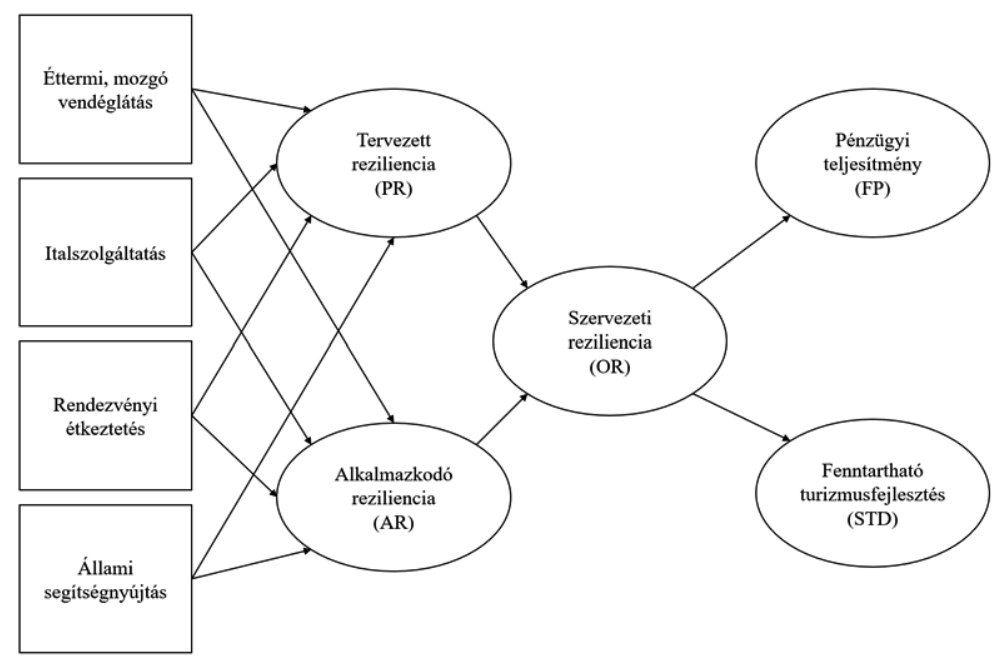

Forrás: saját szerkesztés PRAYAG és társai (2018), valamint SOBAIH és társai (2021) alapján

\section{A vizsgálatba bevonni kívánt vállalkozások piacának helyzete}

\begin{tabular}{|c|c|c|c|c|}
\hline $\begin{array}{l}\text { Gazdasági } \\
\text { tevékenység }\end{array}$ & TEÁOR szám & $\begin{array}{l}\text { Vállalkozások száma } \\
\text { (2021 május) }\end{array}$ & $\begin{array}{c}\text { Alkalmazottak száma } \\
\text { (2021 május) }\end{array}$ & $\begin{array}{c}\text { Éves nettó árbevétel } \\
(2020)\end{array}$ \\
\hline $\begin{array}{l}\text { Éttermi, mozgó } \\
\text { vendéglátás }\end{array}$ & 5610 & $\begin{array}{l}15.240 \\
-2,5 \% \\
\end{array}$ & $\begin{array}{c}73.692 f^{\prime \prime} \\
-22,4 \% \\
\end{array}$ & $\begin{array}{c}582.240 \text { millió Ft } \\
-31,3 \% \\
\end{array}$ \\
\hline Rendezvényi étkeztetés & 5621 & $\begin{array}{c}221 \\
-0,9 \% \\
\end{array}$ & $\begin{array}{l}841 \mathrm{fó} \\
-26,5 \% \\
\end{array}$ & $\begin{array}{c}6.251 \text { millió Ft } \\
-50,2 \%\end{array}$ \\
\hline Italszolgáltatás & 5630 & $\begin{array}{l}3.445 \\
-5,6 \% \\
\end{array}$ & $\begin{array}{l}6.202 f^{\prime \prime} \\
-26,5 \%\end{array}$ & $\begin{array}{c}43.007 \text { millió Ft } \\
-42,1 \%\end{array}$ \\
\hline
\end{tabular}

Forrás: NEMZETI CÉGTÁR (2021)

jelent valódi fejlődést a jövőre nézve. A 2. ábra modelljében van egy változó, a szervezeti reziliencia (OR), ami a modell másodrendú konstruktuma, vagyis a PR és AR faktorokból létrehozott vállalati tulajdonság.

A vizsgálatba a kereskedelmi vendéglátás azon három ágazatából vonnánk be mikro-, és kisvállalkozásokat, melyek egy ország vendéglátóiparának a gerincét adják, egyúttal legnagyobb mértékben járulnak hozzá a szektor teljesítményéhez: az éttermi, mozgó vendéglátás, az italszolgáltatás és a rendezvényi étkeztetés. A szakágazatok szereplőinek számát és 2020. évi teljesítményét a

\section{6. Összefoglalás}

A tanulmány mindkét célkitúzést teljesítette. Az O1-ből kiderült, hogy a Covid és a vendéglátás kapcsolatára irányuló kutatásokban meghatározóak a vállalatelmélet, a marketing, valamint a fogyasztói és szervezeti magatartás elméleti megközelítései. Az itt bemutatott elméletek által inspirált kutatónak két szempontot érdemes figyelembe vennie. Az egyik a kutatás aktualitása, ugyanis a kutató érdeklődése alól könnyen eltûnik a vizsgálni kívánt jelenség. Ezt a 4 . fejezetben két példával is 
alátámasztottuk. A másik a kutatás módszertana, ami egyben az eredmények disszeminációjának szúk keresztmetszete. A minősített folyóiratok jellemzően a többlépcsős, sokváltozós adatelemzési módszerek vagy az alternatív, formabontó kutatási módszerek felé nyitottak.

Az O2-ben saját kutatási keretmunkánk kialakítását leginkább két szempont vezérelte. Olyan tárgykör azonosítása, ami nemcsak a járványügyi intézkedések alatt aktuális, hanem előremutató, a vendéglátás-menedzsment látenciái közé is bepillantást enged. Ehhez olyan validált mérési eszköz és széles körben elfogadott módszerek állnak rendelkezésre, melyek megbízható válaszokat adhatnak az alábbi kérdésekre: mennyire érte felkészülten a vállalkozásokat a koronavírus-járvány; tanultak-e a vállalkozások a járványhelyzet alatti nehézségeikból; felkészülnek-e jövőbeli krízisekre; és hogy a fenntarthatóság szerves részét képezi-e az újjáépülésnek?

\section{Felhasznált irodalom}

BREWER, P. - SEBBY, A. G. (2021): The effect of online restaurant menus on consumers' purchase intentions during the COVID-19 pandemic. International Journal of Hospitality Management. 94 (April).

https://doi.org/10.1016/j.ijhm.2020.102777

BUFQUIN, D. - PARK, J. Y. - BACK, R. M. - DE SOUZA MEIRA, J. V. - HIGHT, S. K. (2021): Employee work status, mental health, substance use, and career turnover intentions: An examination of restaurant employees during COVID-19. International Journal of Hospitality Management. 93 (February). https://doi.org/10.1016/j.ijhm.2020.102764

BYRD, K. - HER, E. S. - FAN, A. - ALMANZA, B. - LIU, Y. - LEITCH, S. (2021): Restaurants and COVID-19: What are consumers' risk perceptions about restaurant food and its packaging during the pandemic? International Journal of Hospitality Management. 94 (April). https://doi.org/10.1016/j.ijhm.2020.102821

CAI, R. - LEUNG, X. Y. (2020): Mindset matters in purchasing online food deliveries during the pandemic: The application of construal level and regulatory focus theories. International Journal of Hospitality Management. 91 (October). https://doi.org/10.1016/j.ijhm.2020.102677

CHEN, H. - EYOUN, K. (2021): Do mindfulness and perceived organizational support work? Fear of COVID-19 on restaurant frontline employees' job insecurity and emotional exhaustion. International Journal of Hospitality Management. 94 (April).

https://doi.org/10.1016/j.ijhm.2020.102850
CHOI, S. - YANG, E. C. L. - TABARI, S. (2020): Solo dining in Chinese restaurants: A mixed-method study in Macao. International Journal of Hospitality Management. 90 (September). https://doi.org/10.1016/j.ijhm.2020.102628

CUTTER, S. L. - AHEARN, J. A. - AMADEI, B. CRAWFORD, P. - EIDE, E. A. - GALLOWAY, G. E. - GOODCHILD, M. F. - KUNREUTHER, H. C. - LI-VOLLMER, M. - SCHOCH-SPANA, M. - SCRIMSHAW, S. C. - STANLEY, E. M. - WHITNEY, G. - ZOBACK, M. L. (2013): Disaster Resilience: A National Imperative. Environment: Science and Policy for Sustainable Development. 55(2). pp. 25-29. https://doi.org/10.1080/00139157.2013.768076

DE FREITAS, R. S. G. - STEDEFELDT, E. (2020): COVID-19 pandemic underlines the need to build resilience in commercial restaurants' food safety. Food Research International. 136. (October). https://doi.org/10.1016/j.foodres.2020.109472

FOROUDI, P. - H. TABAGHDEHI, S. A. - MARVI, R. (2021): The gloom of the COVID-19 shock in the hospitality industry: A study of consumer risk perception and adaptive belief in the dark cloud of a pandemic. International Journal of Hospitality Management. 92 (January). https://doi.org/10.1016/j.ijhm.2020.102717

HINEK M. (2020): A turizmus közvetlen hozzájárulása a magyar gazdaság teljesítményéhez: a Turizmus Szatellit Számlák fejlesztésének alternatívái. Turizmus Bulletin. 20. Különszám. pp. 45-52.

https://doi.org/10.14267/TURBULL.2020v20n4.0

KIM, J. - KIM, J. - WANG, Y. (2021): Uncertainty risks and strategic reaction of restaurant firms amid COVID-19: Evidence from China. International Journal of Hospitality Management. 92 (January). https://doi.org/10.1016/j.ijhm.2020.102752

KIM, J. - LEE, J. C. (2020): Effects of COVID-19 on preferences for private dining facilities in restaurants. Journal of Hospitality and Tourism Management. 45 (December) pp. 67-70. https://doi.org/10.1016/j.jhtm.2020.07.008

LEE, A. V. - VARGO, J. - SEVILLE, E. (2013): Developing a tool to measure and compare organizations' resilience. Natural Hazards Review. 14(1). pp. 29-41. https:// ascelibrary.org/doi/abs/10.1061/\%28ASCE\%29NH.1527-6996.0000075

LI, Y - YAO, J. - CHEN, J. (2021): The negative effect of scarcity cues on consumer purchase decisions in the hospitality industry during the COVID-19 pandemic. International Journal of Hospitality Management. 94. (April). https://doi.org/10.1016/j.ijhm.2020.102815 
LINKOV, I. - TRUMP, B. D. (2019): The science and practice of resilience. Springer.

MADEIRA, A. - PALRAO, T. - MENDES, A. S. (2021): The impact of pandemic crisis on the restaurant business. Sustainability. 13(1). pp. 1-13. https://dx.doi.org/10.3390/su13010040

MUN, S. G. - KOH, Y. - JANG, S. C. (2021): Which Type of M\&A Makes an Acquiring Restaurant Firm a Star? Profit-Driven Versus Growth-Driven M\&A. Cornell Hospitality Quarterly. https://doi.org/10.1177\%2F1938965520979174

OU, J. - WONG, I. K. A. - HUANG, G. Q. I. (2021): The coevolutionary process of restaurant CSR in the time of mega disruption. International Journal of Hospitality Management. 92 (January). https://doi.org/10.1016/j.ijhm.2020.102684

PRAYAG, G. - CHOWDHURY, M. - SPECTOR, S. - ORCHISTON, C. (2018): Organizational resilience and financial performance. Annals of Tourism Research. 73. pp. 193-196. https://doi.org/10.1016/j.annals.2018.06.006

SHAPOVAL, V. - HÄGGLUND, P. - PIZAM, A. ABRAHAM, V. - CARLBÄCK, M. - NYGREN, T. - SMITH, R. M. (2021): The COVID-19 pandemic effects on the hospitality industry using social systems theory: A multi-country comparison. International Journal of Hospitality Management. 94.

https://doi.org/10.1016/j.ijhm.2020.102813

SOBAIH, A. E. E. - ELSHAER, I. - HASANEIN, A. M. - ABDELAZIZ, A. S. (2021): Responses to COVID-19: The role of performance in the relationship between small hospitality enterprises' resilience and sustainable tourism de- velopment. International Journal of Hospitality Management. 94 (April).

https://doi.org/10.1016/j.ijhm.2020.102824

SONG, H. J. - YEON, J. - LEE, S. (2021): Impact of the COVID-19 pandemic: Evidence from the U.S. restaurant industry. International Journal of Hospitality Management. 92 (January). https://doi.org/10.1016/j.ijhm.2020.102702

TAYLOR, S. (2020). The socially distant servicescape: An investigation of consumer preference's during the re-opening phase. International Journal of Hospitality Management. 91 (October). https://doi.org/10.1016/j.ijhm.2020.102692

\section{Internetes források}

KSH (2021): A vendéglátóhelyek forgalma és volumene. https://www.ksh.hu/docs/hun/xstadat/xstadat_ evkozi/e_oga016.html, Letöltve: 2021. május 19.

NEMZETI CEGTÁR (2021): Interaktív grafikon. https://nemzeticegtar.hu/interaktiv-grafikon, Letöltve: 2021. május 19.

STATISTA (2020a): Global tourism industry - statistics $\mathcal{E}$ facts. https://www.statista.com/topics/962/global-tourism/\#dossierSummary, Letöltve: 2021. május 19.

STATISTA (2020b): Leisure tourism spending worldwide from 2000 to 2020. https://www.statista. com/statistics/1093335/leisure-travel-spending-worldwide/, Letöltve: 2021. május 19.

STATISTA (2020c): Business tourism spending worldwide from 2000 to 2020. https://www.statista. com/statistics/1093295/business-travel-spending-worldwide/, Letöltve: 2021. május 19.

WHO (2004): https://www.who.int/mental_ health/evidence/en/promoting_mhh.pdf, Letöltve: 2021. május 19. 